\title{
Attitude and Motivation for Learning English and their Impact on Performance: A Study on Engineering Students of Jessore University of Science and Technology
}

\author{
Md. Abdullah Al Mamun¹, Md. Munibur Rahman¹, Fariha-Tuz-Zahra \\ Chowdhury ${ }^{1}$
}

${ }^{1}$ Department of English, Jessore University of Science and Technology, Jessore-7408, Bangladesh Email: mamunngc@gmail.com

\begin{abstract}
Learners' cognitive, metacognitive, individual differences and demographic characteristics have been found having profound impact on their linguistic performance. This study has tried to observe two such factors namely motivation and attitude of the learners and their impact on the learners' proficiency. An adapted version of AMTB and a TEEP test have been used to statistically measure the level of motivation and attitude of the learners for learning English and the correlation between these two learner factors and their language performance. The study has found that learners' overall motivation level is average though instrumental motivation outscores integrative motivation and they have a mixed attitude towards learning English. Neither motivation nor attitude is significantly correlated with learners' proficiency.
\end{abstract}

Keywords- Attitude, English language teaching, language performance, Learners' characteristics, Motivation.

\section{INTRODUCTION}

Besides being a lingua franca, Eng lish language has made its way into almost every type of academic curriculum in most part of the world. Understandably enough, worldwide use of English is growing and the demand for English language teaching is growing too (Dalby,2002). Bangladeshi context is not an exception. Indeed, here English is the sole foreign language included in the curricula of all academic levels.

A lot many factors are responsible for successful Second Language Learning (SLL). It is a consensus among the Second Language Acquisition (SLA) experts that learner factors play an instrumental role. These factors create individual differences in learning, learning style and finally the success of SLL. Some important factors are age, attitude, aptitude and intelligence, cognitive style, motivation and personality (Ellis, 1985) of which attitude and motivation of the learners are of key importance which can create individual differences in effective language learning (Ellis, 2008). It is natural that the motivation and the attitude of the learners correlate with their language performance. Dörnyei (2004, p. 273) attested that motivation is one of the main determinants of second/foreign language (L2) learning achievement. Again, Gardner(1985, p. 83) said "...based on the literature review, and considering all the issues involved, it seems clear that achievement in a second language is influenced by attitudinal/motivational characteristics". If the learner's attitude towards SLL is positive, learning takes place more easily (Chamber, 1999).

To increase the surrender value of the academic knowledge, most of the universities run English courses like Basic/Communicative English. Jessore University of Science and Technology (JUST) is one of the newly established fast growing universities of Bangladesh. To enable the students to keep pace with the scientific and technological knowledge of the fast world, all the departments here arrange a Communicative English course. Of the nineteen there are six engineering departments. Every year about two hundred fifty students are enrolled in these departments. These students, having completed Higher Secondary Certificate level and followed same syllabus with others in the country, share equal background exposure to English language. Thus a study on them can have nationwide implication and representation.

It is hypothesized that motivation and attitude have significant impact on the performance of the students in the study context. Logically enough, the questions arise if the engineering students of JUST have favourable attitude and positive motivation towards English language learning. Again, it is important to see whether and to what extent their performance is influenced by their attitude and motivation. Thus this study centres around two 
objectives: to measure the relationship between the Engineering students' motivation and attitude towards English Language Learning and their performance and to expose the type of attitude and level of motivation the students have for English language learning.

A few studies have been found about the role and amount of motivation of the learners of English as a second language in Bangladesh. Rukanuddin (2014) in his study "Role of Motivation on the Tertiary Level Students of Bangladesh in Learning English" made a motivation survey on some students of some private university and a public institution and found that "Bangladeshi students specially the tertiary level students of Bangladesh do not learn English to integrate or, assimilate themselves with the culture of the native speakers of English, rather they learn English for some practical purposes like getting high ranking jobs or undertaking higher studies, achieving success in career etc.".

Masum (2016) in his study of analy zing motivation of the Higher Secondary Level students towards ELL has explored that Bangladeshi college students have only academic-result related instrumental motivation.

\section{THEORETICAL FRAMEWORK}

Motivation and attitude are complex individual human traits. They are held responsible for the individual's desire for doing and liking something. They shape the way they want to do something or restrain them from doing something. Thus these two factors have high influence on learning a second language. But they are not directly observable rather manifested through different behavioural tasks.

\subsection{Motivation}

Commonly speaking motivation is an enthusiasm caused by intrinsic or extrinsic factors of the learners which pushes them to reach the desired goal. The subject feels some needs which create inner tensions and stimulate them to be active to satisfy the needs (Murray,1938). Cognitively these factors can reinforce the learners to do appropriate actions though according to behaviourist view the external factors are more important.

According to Gardner (1985) motivation is "the combination of effort plus desire to achieve the goal of learning the language plus favourable attitudes toward learning the language (p. 10). Gardner and Lambert (1959) mentioned two types of motivation: integrative and instrumental. Integrative motivation refers to the learners' desire to integrate them with the target language (TL) culture and feels affinity towards different components of the TL culture. The desire to learn the TL, to interact with the TL, attitude towards the TL learning situation and community are some of the integrativemotivation traits (Gardner, 1982). They feel that the knowledge of the TL will make them identified in terms of the TL culture which they value much.

On the other hand the learners may learn the TL for some realistic or utilitarian purposes. To get a better job or higher salaryor passing the examination are some of the aims they want to materialize with the help of the TL knowledge. That is knowledge in English language is considered an instrument or tool for achieving these goals.

Motivation as an integral factor has multifarious impact on second or foreign language teaching and learning. Stansfield $\&$ W inke (2008) contend that high motivation may lead to more strategies and timeon task which interplays with the learner's existing aptitude and maximizes the learner'spotential (p. 83 as in Rukanuddin, 2014). Indeed, students who are highly motivated do better than those without motivation (Harmer, 1998, p. 8).

\subsection{Attitude}

Motivation and attitude are like Siamese-twins; each manifests through the other. Gardner (2008, p.31) added that attitudes and motivation are often treated together given that attitudes have motivational properties and motivation has attitudinal implications. Even instead of securing high quality instructions, the characteristics of the learners like attitude will determine the actual success (Gardner, 2006, p. 242).

Gardner (1985) has defined attitude as "an evaluative reaction to some referent or attitude object". The mode of attitude of the learners towards TL and TL culture and people has impact on the level of success of TL learning. Gardner (1985) says:

In the language learning situation, if the students' attitudes are favourable, it is reasonable to predict, other things being equal, that the experience with the language be pleasant, and the students will be encouraged to continue. Simply, favourable attitudes tend to cause the experience to be perceived positively. If, on the other hand, attitudes are negative, the experiences will tend to be perceived unfavourably. (p. 8)

Commonly, attitude is someone's positive or negative or mixed feeling towards something or somebody or some idea. It is related to their beliefs and values. Social aspects and background language also have influence on the learners' attitude toward TL and the learning activities. A positive attitude promotes language learning (Chamber, 1999). Our behaviour is determined by attitude and it influences the speed and efficiency of learning (Lambert \& Lambert, 1973, p.77). Kara (2009) stated that, "Positive attitudes lead to the exhibition of positive behaviours toward courses of study, with participants absorbing themselves in courses and striving to learn more. Such students are also observed to be more eager to solve problems, to acquire the information and 
skills useful for daily life and to engage themselves emotionally."

\subsection{Second Language Performance}

Second language performance refers to the capacity of the learners or users to use the language in real life and academic activities. It includes the learners' ability to use the language appropriate to the discourse and genre. As a precondition itnecessitates the knowledge of the language and its formal characteristics and knowledge of the discourse as well as register, which has been termed competence by Chomsky (1957).

\section{METHODOLOGY}

This is an exploratory study. A quali-quantitative approach has been used. Required data were collected from both primary and secondary sources. Primary data have been collected from the relevant field and for secondary data different books, articles, textbooks, and the electronic sources i.e. internet have been consulted.

For measuring motivation and attitude a modified version of Gardner's (2004) AMTB (Attitude and Motivation Test Battery,) has been used. The self-assessment questionnaire had 7 items for integrative and 7 items for instrumental motivation; and 13 items for measuring attitude. The students' motivation and attitude have been measured on the following 7 point Lickert scale.

\begin{tabular}{|c|c|c|c|c|c|c|c|c|}
\hline 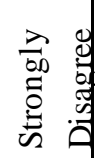 & 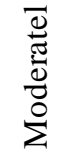 & 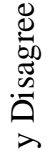 & 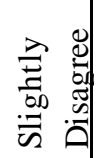 & 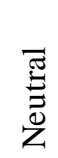 & 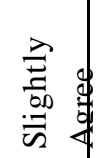 & 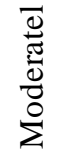 &  & 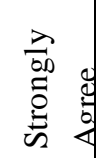 \\
\hline 1 & 2 & & 3 & 4 & 5 & 6 & & 7 \\
\hline
\end{tabular}

For proficiency test, a TEEP (Test of English for Educational Purpose) speaking test was used. Following the TEEP (University of Reading) test criteria, a three minute speaking session was arranged with the students. Grading (out of 20 marks, 5 marks for each item) was done on the following items -

a) Explaining ideas and information

b) Interaction

c) Fluency

d) Grammatical accuracy

The collected data have been analyzed in accordance with the objectives of the study. Some measurements of descriptive statistics have been done following codification and categorization of the data. For validity data were cross checked. For necessary parts computer softwares like Ms Excel, SPSS were used.
A purposive sampling procedure was followed. Data were collected from three of the six engineering departments of Jessore University of Science and Technology. There are about 900 students in these departments. Department wise break down of the respondents was as follows:

Table.1: Respondents for self-assessment questionnaire

\begin{tabular}{|c|c|}
\hline Name of the Departments & No. of Students \\
\hline Genetic Engineering and Bio- & 23 \\
\hline Chemical Engineering & 34 \\
\hline Electrical and Electronic & 31 \\
\hline Total & 88 \\
\hline
\end{tabular}

Table.2: Respondents for TEEP Speaking test

\begin{tabular}{|c|c|}
\hline Name of the Departments & No. of Students \\
\hline Genetic Engineering and Bio- & 23 \\
\hline Chemical Engineering & 33 \\
\hline Total & 56 \\
\hline
\end{tabular}

\section{RESULTS AND DISCUSSION}

\subsection{General Information of the Respondents}

Of the 88 student respondents, 68 are male and 20 are female. As attitude and motivation are subjective aspect of a student and they are affected by their background institutions. Thus they were asked if they completed their Higher Secondary Certificate level from institution of urban or rural area. It has been found that $67 \%$ co mpleted their HSC from urban areas and the rest from rural areas.

4.2 Integrative Motivation

Considering the overall mean of all the items for measuring integrative motivation, the motivation level is average. From items number 4,5,6 and 7, it is clear that they have quite high motivation when the utility of English is concrete in local settings. Thus, they lack intention for integrating with the English speaking nations. They show little interest in intercultural relationship. However, they showed their willingness to use English to get prestige in the society or for educational purpose. They honor the usefulness and prestige attached with competence in English as a global language. It is the global English that has given English speaking people this prestige and honor. It seems that the prestige of English as a language is not due its native users. Lack of acculturation is obvious. Instead of cultural affiliation, they are prone to utilizing English language as a means of communication. The Pearson correlation shows that there is a negative correlation (Pearson Correlation -.015) between the gender and the Integrative motivation.

Table.3: Descriptive Statistics of Integrative Motivation

\begin{tabular}{|c|l|c|c|}
\hline Number & \multicolumn{1}{|c|}{ Items } & Mean & SD \\
\hline 1 & $\begin{array}{l}\text { I study English because I like the countries in which English } \\
\text { is spoken. }\end{array}$ & 2.89 & 1.97 \\
\hline
\end{tabular}




\begin{tabular}{|c|l|c|c|}
\hline 2 & $\begin{array}{l}\text { I study English because I like the culture and civilization of } \\
\text { its native speakers }\end{array}$ & 3.75 & 2.10 \\
\hline 3 & $\begin{array}{l}\text { I study English as I like the people who are citizens of } \\
\text { English speaking countries. }\end{array}$ & 5.03 & 1.81 \\
\hline 4 & $\begin{array}{l}\text { I feel learning English helps to get prestigious position in } \\
\text { society }\end{array}$ & 6.02 & 1.51 \\
\hline 5 & $\begin{array}{l}\text { Studying English is important because it will make me more } \\
\text { educated. }\end{array}$ & 6.39 & 1.05 \\
\hline 6 & $\begin{array}{l}\text { Studying English is important because it will allow me to be } \\
\text { more at ease with people who speak English. }\end{array}$ & 5.03 & 1.79 \\
\hline 7 & $\begin{array}{l}\text { I feel native English speakers have something to be proud of } \\
\text { as English is a global language }\end{array}$ & 4.57 & 1.72 \\
\hline
\end{tabular}

\subsection{Instrumental Motivation}

Table 4 shows that instrumental motivation of the Engineering students is high. Except items number 3 and 5 , means in other items cross 6 , that is, they are near to 'very high'. Thus competence in English language is seen key to achieving success in job related situations. Also, for enhancing academic result they attach much importance to English related knowledge. The mean for item number 5 proves that they do not learn English only for its being a mandatory course.Unlike integrative motivation, gender is positively related (Pearson Correlation 0.118) to instrumental motivation but not significantly.

Table.4: Descriptive Statistics of Instrumental Motivation

\begin{tabular}{|c|l|c|c|}
\hline Number & \multicolumn{1}{|c|}{ Items } & Mean & S D \\
\hline 1 & $\begin{array}{l}\text { Studying English is important because it will be useful in getting a good } \\
\text { job }\end{array}$ & 6.16 & 1.35 \\
\hline 2 & $\begin{array}{l}\text { Studying English is important because I will need it for better salary and } \\
\text { promotion }\end{array}$ & 5.39 & 1.44 \\
\hline 3 & I take English course to acquire some credit & 3.64 & 2.16 \\
\hline 4 & Competence in English will enhance my academic result & 5.23 & 1.49 \\
\hline 5 & I learn English because it is a compulsory course & 3.65 & 2.06 \\
\hline 6 & English is important for me because I need it for going abroad & 5.73 & 1.74 \\
\hline 7 & $\begin{array}{l}\text { English is important for me because I want to acquire knowledge of } \\
\text { various fields and English is the most-used language }\end{array}$ & 6.52 & 0.85 \\
\hline \multicolumn{1}{|c|}{ Overall } & 5.18 & 1.58 \\
\hline
\end{tabular}

If we compare students' integrative and instrumental motivation for language learning, the latter far outweighs the former. Thus it can be said that students have a bit more than average motivation which is dominated by instrumental motivation.

\subsection{Attitude}

In attitude section, there were two types of items. First seven questions elicited students' attitudetowards English Language Learning using positive statements and the last six items derived attitude using negative statement. For the first seven items, the overall mean i.e. 5.59 shows that they have quite a positive attitude but not satisfactory enough expected of the successful learners.As the table 4 shows in all the items less than 50\% students (in items number 5, 6 and 7 around 30\% only)strongly agree with the statements. To respond to whether they enjoy learning English $49 \%$ students strongly agree and $30 \%$ moderately agree. They also don't want to spend much time in the English classes $(16 \%$ strongly agree and $28.4 \%$ moderately agree). About $20 \%$ students said that English is not one of their favourite courses. It is obvious that they study English because they have it as a mandatory subject.

Table.5: Descriptive Statistics of Attitude-Positive(fand \%)

\begin{tabular}{|c|c|c|c|c|c|c|c|c|c|c|}
\hline $\begin{array}{l}\mathrm{Nu} \\
\mathrm{mb} \\
\mathrm{er}\end{array}$ & Items & 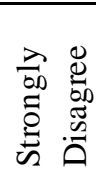 &  & 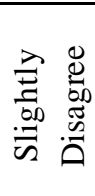 & $\begin{array}{l}\bar{\pi} \\
\stackrel{\Xi}{0} \\
\bar{Z}\end{array}$ & 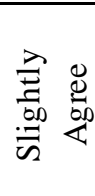 & 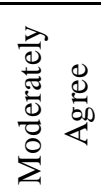 & 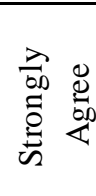 & Mean & S D \\
\hline 1 & $\begin{array}{l}\text { I pay high attention to the } \\
\text { feedback I receive in my } \\
\text { English class. }\end{array}$ & $\begin{array}{c}0 \\
(0)\end{array}$ & $\begin{array}{c}1 \\
(1.1)\end{array}$ & $\begin{array}{c}0 \\
(0)\end{array}$ & $\begin{array}{c}13 \\
(14.8)\end{array}$ & $\begin{array}{c}10 \\
(11.4)\end{array}$ & $\begin{array}{c}24 \\
(27.3)\end{array}$ & $\begin{array}{c}40 \\
(45.5)\end{array}$ & 6.00 & 1.16 \\
\hline
\end{tabular}




\begin{tabular}{|c|l|c|c|c|c|c|c|c|c|c|}
\hline 2 & $\begin{array}{l}\text { I look forward to going to } \\
\text { class because my English } \\
\text { teacher is so good. }\end{array}$ & $\begin{array}{c}2 \\
(2.3)\end{array}$ & $\begin{array}{c}2 \\
(2.3)\end{array}$ & $\begin{array}{c}2 \\
(2.3)\end{array}$ & $\begin{array}{c}9 \\
(10.2)\end{array}$ & $\begin{array}{c}16 \\
(18.2)\end{array}$ & $\begin{array}{c}23 \\
(26.1)\end{array}$ & $\begin{array}{c}34 \\
(38.6)\end{array}$ & 5.73 & 1.43 \\
\hline 3 & $\begin{array}{l}\text { I really enjoy learning } \\
\text { English }\end{array}$ & $\begin{array}{c}4 \\
(4.5)\end{array}$ & $\begin{array}{c}1 \\
(1.1)\end{array}$ & 0 & $\begin{array}{c}3 \\
(3.4)\end{array}$ & $\begin{array}{c}11 \\
(12.5)\end{array}$ & $\begin{array}{c}26 \\
(29.5)\end{array}$ & $\begin{array}{c}43 \\
(48.9)\end{array}$ & 6.02 & 1.44 \\
\hline \multirow{2}{*}{4} & $\begin{array}{l}\text { I like my English class so } \\
\text { much that I look forward to } \\
\text { studying more English in } \\
\text { the future. }\end{array}$ & $\begin{array}{c}5 \\
(5.7)\end{array}$ & $\begin{array}{c}3 \\
(3.4)\end{array}$ & $\begin{array}{c}2 \\
(2.3)\end{array}$ & $\begin{array}{c}4 \\
(4.5)\end{array}$ & $\begin{array}{c}14 \\
(15.9)\end{array}$ & $\begin{array}{c}24 \\
(27.3)\end{array}$ & $\begin{array}{c}36 \\
(40.9)\end{array}$ & 5.67 & 1.68 \\
\hline 5 & $\begin{array}{l}\text { I look forward to the time I } \\
\text { spend in English class. }\end{array}$ & $\begin{array}{c}9 \\
(10.2)\end{array}$ & $\begin{array}{c}3 \\
(3.4)\end{array}$ & $\begin{array}{c}5 \\
(5.7)\end{array}$ & $\begin{array}{c}21 \\
(23.9)\end{array}$ & $\begin{array}{c}11 \\
(12.5)\end{array}$ & $\begin{array}{c}25 \\
(28.4)\end{array}$ & $\begin{array}{c}14 \\
(15.9)\end{array}$ & 4.74 & 1.81 \\
\hline 6 & $\begin{array}{l}\text { I enjoy the activities in the } \\
\text { English class }\end{array}$ & $\begin{array}{c}1 \\
(1.1)\end{array}$ & $\begin{array}{c}1 \\
(1.1)\end{array}$ & $\begin{array}{c}3 \\
(3.4)\end{array}$ & $\begin{array}{c}6 \\
(6.8)\end{array}$ & $\begin{array}{c}14 \\
(15.9)\end{array}$ & $\begin{array}{c}31 \\
(35.2)\end{array}$ & $\begin{array}{c}32 \\
(36.4)\end{array}$ & 5.86 & 1.25 \\
\hline 7 & $\begin{array}{l}\text { English is one of my } \\
\text { favourite courses }\end{array}$ & $\begin{array}{c}8 \\
(9.1)\end{array}$ & $\begin{array}{c}4 \\
(4.5)\end{array}$ & $\begin{array}{c}6 \\
(6.8)\end{array}$ & $\begin{array}{c}9 \\
(10.2)\end{array}$ & $\begin{array}{c}11 \\
(12.5)\end{array}$ & $\begin{array}{c}21 \\
(23.9)\end{array}$ & $\begin{array}{c}29 \\
(33)\end{array}$ & 5.16 & 1.95 \\
\hline
\end{tabular}

On the other hand, the overall mean (2.63) of the items for eliciting attitude using negativestatements proves that they have negative attitude though not high but not negligible. In cases of items 9, 11, and 12, they have considerable negative attitude.They are most likely not to keep learning English once the examination is over (Means of items number 10 and 13).

Table.6: Descriptive Statistics of Attitude-Negative(fand \%)

\begin{tabular}{|c|c|c|c|c|c|c|c|c|c|c|}
\hline No. & Items & 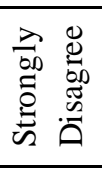 & 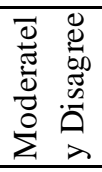 & 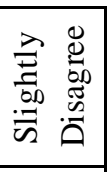 & 焉 &  & 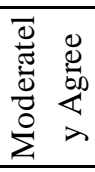 & \begin{tabular}{ll|}
$\frac{\lambda}{00}$ & 0 \\
$\vdots$ & 0 \\
0 & 0 \\
$\vdots$ & 0
\end{tabular} & $\begin{array}{c}\text { Mea } \\
\mathrm{n}\end{array}$ & S D \\
\hline 8 & $\begin{array}{l}\text { My English class is really a } \\
\text { waste of time. }\end{array}$ & $\begin{array}{c}77 \\
(87.5) \\
\end{array}$ & $\begin{array}{c}5 \\
(5.7) \\
\end{array}$ & $\begin{array}{c}2 \\
(2.3)\end{array}$ & $\begin{array}{c}1 \\
(1.1)\end{array}$ & $\begin{array}{c}1 \\
(1.1)\end{array}$ & $\begin{array}{c}1 \\
(1.1) \\
\end{array}$ & $\begin{array}{c}1 \\
(1.1) \\
\end{array}$ & 1.31 & 1.02 \\
\hline 9 & $\begin{array}{l}\text { It embarrasses me to } \\
\text { volunteer answers in our } \\
\text { English class }\end{array}$ & $\begin{array}{c}28 \\
(31.8)\end{array}$ & $\begin{array}{c}5 \\
(5.7)\end{array}$ & $\begin{array}{c}9 \\
(10.2)\end{array}$ & $\begin{array}{c}18 \\
(20.5)\end{array}$ & $\begin{array}{c}11 \\
(12.5)\end{array}$ & $\begin{array}{c}10 \\
(11.4)\end{array}$ & $\begin{array}{l}7 \\
(8)\end{array}$ & 3.42 & 2.05 \\
\hline 10 & $\begin{array}{l}\text { I sometimes daydream } \\
\text { about dropping English }\end{array}$ & $\begin{array}{c}41 \\
(46.6)\end{array}$ & $\begin{array}{l}7 \\
(8)\end{array}$ & $\begin{array}{c}3 \\
(3.4)\end{array}$ & $\begin{array}{c}25 \\
(28.4)\end{array}$ & $\begin{array}{c}3 \\
(3.4)\end{array}$ & $\begin{array}{c}4 \\
(4.5)\end{array}$ & $\begin{array}{c}5 \\
(5.7)\end{array}$ & 2.70 & 1.90 \\
\hline 11 & $\begin{array}{l}\text { I put off my English } \\
\text { homework as much as } \\
\text { possible }\end{array}$ & $\begin{array}{c}36 \\
(40.9)\end{array}$ & $\begin{array}{c}12 \\
(13.6)\end{array}$ & $\begin{array}{c}3 \\
(3.4)\end{array}$ & $\begin{array}{c}9 \\
(10.2)\end{array}$ & $\begin{array}{c}12 \\
(13.6)\end{array}$ & $\begin{array}{c}8 \\
(9.1)\end{array}$ & $\begin{array}{c}8 \\
(9.1)\end{array}$ & 3.06 & 2.47 \\
\hline 12 & $\begin{array}{l}\text { My English teacher is one } \\
\text { of the least pleasant people I } \\
\text { know. }\end{array}$ & $\begin{array}{c}36 \\
(40.9)\end{array}$ & $\begin{array}{c}7 \\
(8)\end{array}$ & $\begin{array}{c}3 \\
(3.4)\end{array}$ & $\begin{array}{c}15 \\
(17)\end{array}$ & $\begin{array}{c}9 \\
(10.2)\end{array}$ & $\begin{array}{c}13 \\
(14.8)\end{array}$ & $\begin{array}{c}5 \\
(5.7)\end{array}$ & 3.15 & 2.13 \\
\hline 13 & $\begin{array}{l}\text { When I leave University, I } \\
\text { will give up the study of } \\
\text { English because I am not } \\
\text { interested in it. }\end{array}$ & $\begin{array}{c}53 \\
(60.2)\end{array}$ & $\begin{array}{c}11 \\
(12.5)\end{array}$ & $\begin{array}{c}8 \\
(9.1)\end{array}$ & $\begin{array}{c}3 \\
(3.4)\end{array}$ & $\begin{array}{c}4 \\
(4.5)\end{array}$ & $\begin{array}{c}5 \\
(5.7)\end{array}$ & $\begin{array}{c}4 \\
(4.5)\end{array}$ & 2.15 & 1.81 \\
\hline \multicolumn{9}{|c|}{ Overall } & 2.63 & 1.89 \\
\hline
\end{tabular}

It is found that about $30 \%$ students feel embarrassed to talk spontaneously in the classroom. They are found having developed an aversion to doing homework. 


\section{It embarrasses me to volunteer answers in our English class(\%)}
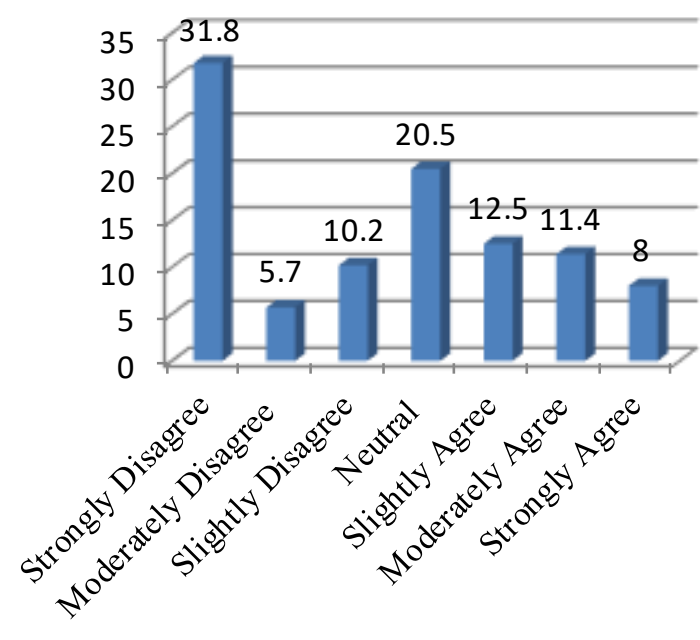

Fig.1: Volunteering answer in the classroom

\subsection{Proficiency}

For the TEEP Speaking test all the respondents were not available. 56 students from two departments sat the test. Average proficiency was found to be 13.63 (standard deviation 1.45). The maximum mark gained by the students was 16 and minimum 10. The SD shows that there is not significant difference between students' proficiency levels.

4.6 Correlation between Motivation and Proficiency

There were seven items for measuring integrative motivation. It has been found that correlation between the integrative motivation and the proficiency is insignificant. In case of item 7, they have significant negative correlation. This is quite natural as the students have instrumental motivation (mean 5.18) more than integrative motivation (4.57). This lack of correlation between integrative motivation and proficiency may have resulted from the students' 'contextual and cultural' (Rukanuddin, 2014) detachment from the native English speakers.

Table 7. Correlation between Integrative Motivation and Proficiency

\begin{tabular}{|c|c|c|c|}
\hline No & Items & $\begin{array}{l}\text { Pearson } \\
\text { Correlation }\end{array}$ & Sig. (2-tailed) \\
\hline 1 & I study English because I like the countries in which English is spoken. & .115 & .401 \\
\hline 2 & I study English because I like the culture and civilization of its native speakers & -.263 & .050 \\
\hline 3 & I study English as I like the people who are citizens of English speaking countries. & .019 & .890 \\
\hline 4 & I feel learning English helps to get prestigious position in society & .099 & .469 \\
\hline 5 & Studying English is important because it will make me more educated. & -.072 & .598 \\
\hline 6 & $\begin{array}{l}\text { Studying English is important because it will allow me to be more at ease with } \\
\text { people who speak English. }\end{array}$ & -.070 & .608 \\
\hline 7 & $\begin{array}{l}\text { I feel native English speakers have something to be proud of as English is a global } \\
\text { language }\end{array}$ & $-.375^{* *}$ & .004 \\
\hline
\end{tabular}

$* *$ Correlation is significant at the 0.01 level (2-tailed)

*Correlation is significant at the 0.05 level (2-tailed)

For measuring the relationship between the instrumental motivation and proficiency, six items were used to elicit responses. It has been found that (Table 8) item nu mber 9 is significantly correlated with proficiency. Except this, there remains insignificant correlation between all other items and proficiency. The traditional emphasis on knowledge of English for getting good jobs and salary- promotion has developed this motivation. But it is to be noted that item number 12 is negatively correlated with proficiency. It proves that there is strong wash-back effect. The students have devised some way of passing the compulsory course i.e. English other than acquiring proficiency in the language itself.

Table.8: Correlation between Instrumental Motivation and Proficiency $(N=56)$

\begin{tabular}{|c|l|c|c|}
\hline No & \multicolumn{1}{|c|}{ Items } & Pearson Correlation & Sig. (2-tailed) \\
\hline 8 & $\begin{array}{l}\text { Studying English is important because it will be useful in getting a good } \\
\text { inh }\end{array}$ & .003 & .983 \\
\hline 9 & $\begin{array}{l}\text { Studying English is important because I will need it for bettersalary and } \\
\text { promotion }\end{array}$ &. $\mathbf{3 5 7 ^ { * * }}$ & .007 \\
\hline
\end{tabular}




\begin{tabular}{|c|l|c|c|}
\hline 10 & I take English course to acquire some credit & .200 & .143 \\
\hline 11 & Competence in English will enhance my academic result & .002 &. $.277^{*}$ \\
\hline 12 & I learn English because it is a compulsory course & .036 & .038 \\
\hline 13 & English is important for me because I need it for going abroad & -.033 & .791 \\
\hline 14 & $\begin{array}{l}\text { English is important for me because I want to acquire knowledge of } \\
\text { various fields and English is the most-used language }\end{array}$ & .810 \\
\hline
\end{tabular}

$* *$ Correlation is significant at the 0.01 level (2-tailed)

* Correlation is significant at the 0.05 level (2-tailed)

4.7 Correlation between Attitude and Proficiency

Table 9 shows that out of 13 attitude ite ms, two (items 5 and 6) have significant correlation (at 0.05 level) with proficiency. Five items i.e. items number 2,8,9,10,11 have negative but not significant correlation. And the rest six items have positive but insignificant correlation. The two items having significant correlation with proficiency are "It embarrasses me to volunteer answers in our English class" and "I sometimes daydream about dropping

\section{Table.9: Correlation between Attitude and Proficiency $(N=56)$}

English". They are strong constituents of cognitive attitude. Thus, regarding the overall situation, it can be said that attitude and proficiency in English are not significantly correlated. At the same time the two items having significant correlation with proficiency are not to be neglected. It portends that the students have positive attitude because English is a mandatory course and they have awareness of English being important for instrumental achievement.

\begin{tabular}{|c|c|c|c|}
\hline & Items & $\begin{array}{c}\text { Pearson } \\
\text { Correlation }\end{array}$ & $\begin{array}{c}\text { Sig. } \\
\text { (2-tailed) }\end{array}$ \\
\hline 1 & I pay high attention to the feedback I receive in my English class. & .000 & 1.000 \\
\hline 2 & I look forward to going to class because my English teacher is so good. & -.199 & .142 \\
\hline 3 & My English class is really a waste of time. & .012 & .931 \\
\hline 4 & I really enjoy learning English & .049 & .723 \\
\hline 5 & It embarrasses me to volunteer answers in our English class & $.297^{*}$ & .026 \\
\hline 6 & I sometimes daydream about dropping English & $.295^{*}$ & .027 \\
\hline 7 & I put off my English homework as much as possible & .134 & .324 \\
\hline 8 & My English teacher is one of the least pleasant people I know. & -.058 & 670 \\
\hline 9 & $\begin{array}{l}\text { I like my English class so much that I look forward to studying more } \\
\text { English in the future. }\end{array}$ & -.185 & .171 \\
\hline 10 & I look forward to the time I spend in English class. & -.187 & .167 \\
\hline 11 & I enjoy the activities in the English class & -.102 & .456 \\
\hline 12 & $\begin{array}{l}\text { When I leave University, I will give up the study of English because I } \\
\text { am not interested in it. }\end{array}$ & .074 & .590 \\
\hline 13 & English is one of my favourite courses & .108 & .427 \\
\hline
\end{tabular}

\section{CONCLUSION}

The aim of this paper was to measure learners' motivation, attitude and their impact on students' performance. The results of this research present some unique observations. The quail-quantitative study indicates that learners have positive intention to securing achievements in terms of professional and academic excellence by learning English language and their instrumental motivation is greater than integrative one. In case of attitude, it is found that students need to increase their positive attitude towards learning English to accelerate their success. Otherwise their existing 
instrumental motivation will not be found effective to make them efficient learners of the language. The study sheds light on the fact that, students' attitude encapsulates the mindset of learning English only as a mandatory course and they tend to discontinue learning English once the course is over. Most of the students did not have the orientation of speaking English in the classroom because most of the Bangladeshi higher secondary institutions lack this practice (Brunfaut\& Green, 2017). As a result, when they come to tertiary level, they cannot be spontaneous enough to elicit individual responses in English during the class time.

While examining the reciprocal connection between motivation and proficiency, the study came to observe that as students have little or no contact with native English speakers, there are insignificant correlation between proficiency and integrative motivation. In terms of instrumental motivation, students want to gain proficiency essentially to secure a good job with financial benefits. Although the study found no significant correlation between students' attitude and proficiency, it cannot be neglected that students have positive attitude for learning English as it is a mandatory course in their syllabus and learning English ensures their instrumental achievement. Based on the observations of the study, it can be said that students should adopt positive attitude towards continuously sharpening their English language skills and embrace it as a life-long-learning process. They also need to have a rational balance of integrative and instrumental motivation to enhance their actual learning of the language as well as its use in higher academic achievements. When these aspects become dominant in their mind only then they can have the full benefit from the English courses designed for them.

\section{REFERENCES}

[1] Brunfaut, T. \& Green, R. (2017). English Listening and Speaking Assessment in Bangladesh Higher Secondary Schools: A Baseline Study.

[2] Chamber, G. N. (1999). Motivating language learners. Clevedon: Multilingual Matters.

[3] Dalby A. (200). Language in Danger. London: Penguin Book.

[4] Dörnyei, Z. (1994). Motivation and motivating in the foreign language classroom. The Modern Language Journal, 78 (iii).

[5] Ellis R. (1985). Understanding second language acquisition Oxford: Oxford press.

[6] Ellis R. (2008). The study of second language acquisition, Oxford: Oxford press.

[7] Gardner, R. C. (1985). Social psychology and second language learning: the role of attitudes and motivation. Baltimore, Maryland: Edward Arnold. manual.pdf
[8] Gardner, R. C. (2004). Attitude Motivation Test Battery: International AMTB Research Project. Canada: The University of Western Ontario.

[9] Gardner, R. C. (2006). The Socioeducational Model of Second Language Acquisition: A research paradigm. In S.H. Foster-Cohen, M. Medved Kajnovic, \& J. Mihaljevic Djigunovic (Eds.), Eurosla Yearbook, 6,1, (pp. 237-260). (Annual Conference of the European Second Language Association). Amsterdam: John Benjamin Publishing.

[10] Gardner, R. C. (2008). Individual differences in second and foreign language learning. In $\mathrm{N}$. Van Deusen-Scholl \& N.H. Hornberger (Eds.), Encyclopedia of Language and Education, 4. [Second and Foreign Language Education](pp. 29 40).

[11] Gardner, R.C. (1982). Language attitudes and language learning. In E. Boudhard Ryan \& H. Giles, Attitudes towards language variation (pp. 132-147). London: Edward Arnold.

[12] Harmer, J. (1998). How to Teach English. Edinburgh: Longman.

[13] Kara, A. (2009). The Effect of a 'Learn ing Theories' Unit on Students' Attitudes towards Learning. Australian Journal of Teacher Education, 34(3), 100113.

[14] Lambert, W.W., \&Lamnert, W.E. (1973). Social psychology. Englewood Cliffs, N.J.: Prentice-Hall, Inc.

[15] Masum, M. Z. H.J. (2016). Motivation of Bangladeshi Higher Secondary Students in Learning English Language. Language in India, 16(2).

[16] Murray, H. (1938). Explorations in Personality. Oxford: Oxford University Press.

[17] Rukanuddin, M. (2014). Role of Motivation on the Tertiary Level Students of Bangladesh in Learning English. Research on Humanities and social Sciences, 4 (27), $76-100$ 